\title{
HEALTH-RELATED QUALITY OF LIFE IN SICKLE CELL DISEASE PATIENTS IN AKRE, IRAQI KURDISTAN
}

\author{
DLAN AMEER TAHIR, MBCHB* \\ NASIR AL-ALLAWI, MBCHB, MSC, PHD, FRCPATH** \\ VIAN MANSOUR KHADUM, MBCHB, FIBMS*** \\ ALI JASIM MOHAMMED, MBCHB, FIBMS****
}

\section{Submitted 01 January 2019; accepted 26 June 2019}

\begin{abstract}
Background: Sickle cell disease is an important health problem in Akre- Iraqi Kurdistan, and this study aimed to assess health-related quality of life (HRQoL) in this condition.

Patients and Methods: A total of 63 patients registered as sickle cell disease at Akre thalassemia center in Kurdistan, and an equivalent number of age and sex matched healthy individuals, were recruited. The patient records were retrieved and their clinical and laboratory findings reviewed. Children and adolescent had their HRQoL assessed using PedsQL 4.0 generic score, while the Medical outcome study 36 item short form (SF-36) was used for adults.

Results: The mean age \pm SD of the enrolled patients was $15.43 \pm 8.79$ years, and included 44 females and 19 males. The overall mean HRQoL in both children and adults were significantly worse than respective healthy counterparts, and adults fared worse than children. Among the predictors of low quality life were the occurrence of painful episodes, transfusion frequency, S. Ferritin $\geq 2500 \mathrm{ng} / \mathrm{ml}, \mathrm{LDH} \geq 700 \mathrm{U} / \mathrm{L}$, and avascular necrosis of femoral head $(\mathrm{P}=0.02,0.007,0.012,0.025$ and 0.002 respectively).

Conclusions: Both children and adults with sickle cell disease at Akre thalassemia center had worse quality of life compared to their healthy counterparts. Several predictors for a worse HRQoL were identified, in the studied cohort. Further studies from other centers are necessary to have a more comprehensive view of the HRQoL in Iraqi Kurdistan.
\end{abstract}

Duhok Med J 2019; 13 (2): 31-43. Keywords: Health-related Quality of Life, HRQoL, Iraq, Sickle cell disease, SF-36, PedsQL.

$\mathbf{S}$ ickle cell disease $(\mathrm{SCD})$ is an variety of crises particularly vaso-
hemoglobin disorder due to the substitution of valine for glutamic acid at position 6 of $\beta$-globin chain of hemoglobin, which leads to the formation of hemoglobin $\mathrm{S}$. Hemoglobin $\mathrm{S}$ polymerizes upon de-oxygenation leading to a phenotype characterized by chronic hemolytic process, often accentuated by a occlusive ones, culminating in multi-organ damage $^{1}$; In addition to its effects on physical functioning, SCD also exerts social, psychological, emotional, and academic impact on the life of the affected individual $^{2}$.

Over the past few decades, the concept of health-related quality of life (HRQoL) and its assessment gained wide popularity,

\footnotetext{
* Department of Hematology, Azadi Teaching Hospital, Duhok, Kurdistan region, Iraq

** Professor, Department of Pathology, College of Medicine, University of Duhok, Duhok, Kurdistan Region, Iraq

*** Department of Hematology, Azadi Teaching Hospital, Duhok, Kurdistan region, Iraq

**** Golan Hospital, Duhok, Akre, Kurdistan Region, Iraq.

Correspondence author to: Nasir Al-Allawi, nallawi@yahoo.com, Mobil +9647504551494
}

https://doi.org/10.31386/dmj.2019.12.1.4 
since it measures the patient's perception of the effect of the illness on his/her wellbeing and ability to function in several domains including physical, mental and social domains of life $^{3}$.

There are numerous HRQoL instruments, the most common generic tool that has been used in children with chronic diseases is the 23 item PedsQL generic core scale, which include a parent-proxy and child self-report versions. ${ }^{4}$ In adults, on the other hand, the Medical outcome study 36 item short form [RAND 36 (SF-36)] is the most popular generic instrument used ${ }^{3,5-7}$.

To our knowledge there are no studies addressing the HRQoL in Iraqi Kurds with SCD, and because of the importance of this assessment and its possible impact on patients' management and wellbeing, the current study was initiated aiming at assessing the HRQoL in SCD, and at determining the predictors associated with lower HRQoL in a single center in Akre, Kurdistan, Iraq.

\section{PATIENTS AND METHODS}

This study was conducted at the thalassemia center in Akre -Kurdistan, Iraq during the period between May 2018 and August 2018.

All 67 registered patients with the diagnosis of sickle cell disease at the center were approached and recalled. A total of 63 consented to participate in the study. The patients had their original diagnoses reconfirmed by hematological and/or molecular studies as required. The patients included 41 children and adolescents (5-17 years old) and 22 adults (18-40 years old). They included 19 males and 44 females. Additionally, sixty-three apparently healthy individuals from the same locality, who are age and sex matched with the patients, were assigned as a control or comparison group.

All patients had their records reviewed and had a detailed history and clinical examination, full blood counts by a hematology analyzer (Sysmex XP300USA), reticulocyte count, serum lactic dehydrogenase, S. Ferritin, sickling test by routine laboratory procedures, and high performance liquid chromatography using Beta short program on Bio-Rad D-10 instrument (Bio-Rad, CA, USA).

For children the HRQoL was assessed using the Pediatric Quality of Life Inventory $^{\mathrm{TM}}$ (PedsQL $^{\mathrm{TM}}$ ) 4.0 Generic Core Scale-Kurdish language version, ${ }^{4}$ after the completion of the relevant user agreement form. The Kurdish translation was prepared earlier and linguistically validated and approved by the owner Dr James Varni (Mapi Research TrustFrance $)^{8}$. Based on the latter study, this Kurdish version was found to have a Cronbach's alpha reliability for internal consistency of 0.88 and 0.87 for overall score in child and parent proxy reports respectively ${ }^{8}$, which is considered quite acceptable. PedsQL generic score scale consists of 23 items which could be used for healthy, acutely and chronically ill children and adolescents. The scoring process has been detailed elsewhere ${ }^{4}$, though in summary: a five-point scoring system is used, where 0 denotes no problem, while 4 almost always a problem. These items are arranged in four domains, eight in physical, and five in each of emotional, social and school functioning. The outcome is a total score in each of the four domains and an overall mean score. Each scale is reverse scored from 0-100, 
with the higher values indicating better life quality. $^{4}$

For adults the RAND-36 (SF36) questionnaire was applied to evaluate the impact of the disease on these patients. SF36 is multidimensional questionnaire with 36 items divided into 8 domains: 10 items for physical functioning, 5 items each for emotional well-being and general health, 4 items each for role limitation due to physical health and energy fatigue, 3 items for role limitation due to emotional problem, 2 items each for social functioning and pain. The resultant scores ranges from 0 to 100 , where higher figures represent better quality of life ${ }^{3,9}$. The scoring process is a rather lengthy two-step process which has been detailed elsewhere6.The forms, whether for adults or children, were self-reported, except in those $<$ 8years old, or if the participant was illiterate.

All statistical analyses were performed using SPSS software (SPSS Inc, Chicago, IL, USA). Two tailed independent t-test and Pearson correlation were used, as required. P-value $<0.05$ was considered significant.

The study was approved by the ethics committee at the Kurdistan board of medical specialties and directorate of health in Duhok, Iraq. Informed verbal consent was obtained from all enrollees or their guardians.

\section{RESULTS}

The current study included 63 patients with a mean age of 15.43 (SD 8.79) years, and comprised 44 females and 19 males. The study group included 41 children and 22 adults. In addition, 63 age and sex matched healthy individuals who had a mean age of 15.3 (SD 8.68) were concomitantly recruited.

Table (1) and (2) outline the main clinical and laboratory features of the 63 patients at the time of enrollment as well the cumulative disease specific complications. For children the overall mean HRQoL score was found to be $62.8 \%$ (SD 21.15). The lowest scores for the domains examined was for physical health at $42.89 \%$ (SD 30.65), while the highest was for social functioning at $76.46 \%$ (SD 15.01). When patients were compared to their healthy counterparts, there were significant differences between the overall mean score, as well as all domains except for emotional functioning (Table 3A). There were no significant differences in HRQoL between male and female patients, whether in overall scores or scores in each domain ( $>0.05$ in all). Moreover, Pearson correlation demonstrated that the overall mean scores were significantly correlated between child's report and parent proxy reports $(r=0.75 ; p<0.001)$ [Figure 1].

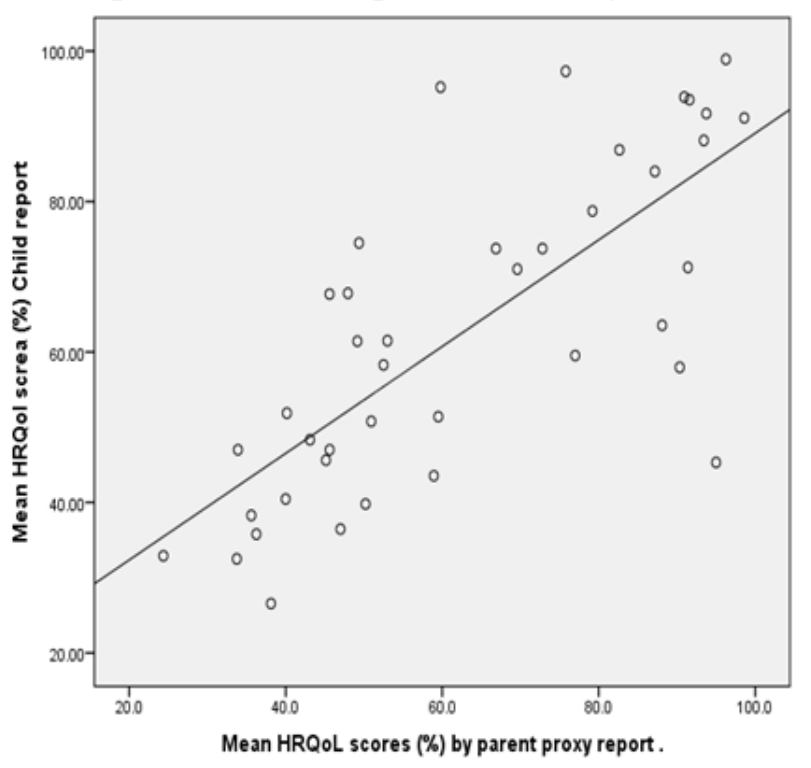

Figure1: Correlation between Mean HRQoL Scores in Child and Parent-Proxy Reports. 


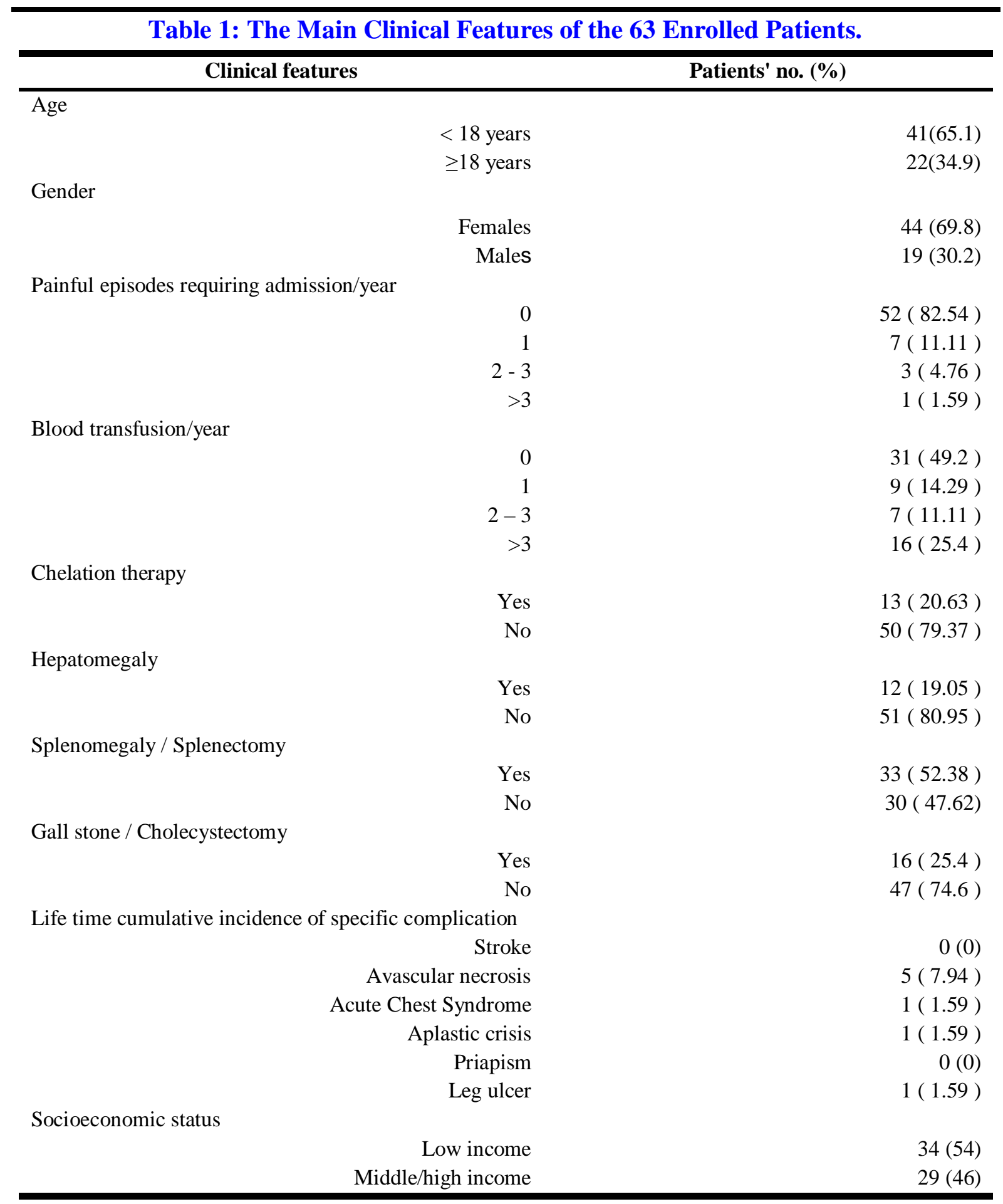


Table 2: The Main Laboratory Parameters among 63 SCD Patients Enrolled. Laboratory Features Patients no. (\%)

\begin{tabular}{|c|c|c|}
\hline \multicolumn{3}{|l|}{ Hemoglobin } \\
\hline & $\geq 9 \mathrm{~g} / \mathrm{dl}$ & $23(36.51)$ \\
\hline & $\geq 8-<9 \mathrm{~g} / \mathrm{dl}$ & $21(33.33)$ \\
\hline & $6-<8 \mathrm{~g} / \mathrm{dl}$ & $16(25.4)$ \\
\hline & $<6 \mathrm{~g} / \mathrm{dl}$ & $3(4.76)$ \\
\hline \multicolumn{3}{|c|}{ Leucocyte count } \\
\hline & $<11,000 \mathrm{~mm}^{3}$ & $37(58.73)$ \\
\hline & $11,000-15,000 \mathrm{~mm}^{3}$ & $14(22.22)$ \\
\hline & $>15,000 \mathrm{~mm}^{3}$ & $12(19.05)$ \\
\hline \multicolumn{3}{|c|}{ Reticulocyte count } \\
\hline & $<5 \%$ & $7(11.11)$ \\
\hline & $6-10 \%$ & $17(26.98)$ \\
\hline & $11-15 \%$ & $15(23.81)$ \\
\hline & $\geq 16 \%$ & $24(38.1)$ \\
\hline \multicolumn{3}{|l|}{$\mathrm{HbF} \%$} \\
\hline & $<5 \%$ & $16(25.4)$ \\
\hline & $5-10 \%$ & $20(31.75)$ \\
\hline & $10.1-14.9 \%$ & $19(30.15)$ \\
\hline & $\geq 15 \%$ & $8(12.7)$ \\
\hline \multicolumn{3}{|c|}{ L.D.H. ( on 57 case ). } \\
\hline & $<700 \mathrm{U} / \mathrm{L}$ & $48(84.2)$ \\
\hline & $\geq 700 \mathrm{U} / \mathrm{L}$ & $9(15.8)$ \\
\hline \multicolumn{3}{|c|}{ S.Ferritin ( on 62 case ). } \\
\hline & Female $\leq 250 \mathrm{ng} / \mathrm{ml}$ & $20(32.26)$ \\
\hline & Female $>250 \mathrm{ng} / \mathrm{ml}$ & $23(37.1)$ \\
\hline & Male $\leq 350 \mathrm{ng} / \mathrm{ml}$ & $5(8.06)$ \\
\hline & Male > $350 \mathrm{ng} / \mathrm{ml}$ & $14(22.58)$ \\
\hline & Overall $<2500 \mathrm{ng} / \mathrm{ml}$ & $50(80.65)$ \\
\hline & Overall $\geq 2500 \mathrm{ng} / \mathrm{ml}$ & $12(19.35)$ \\
\hline \multicolumn{3}{|c|}{ HCV. antibody } \\
\hline & Yes & $5(7.94)$ \\
\hline & No & $58(92.06)$ \\
\hline \multicolumn{3}{|l|}{ HbS Antigen } \\
\hline & Yes & $0(0)$ \\
\hline & No & $63(100)$ \\
\hline
\end{tabular}


For adult patients the overall mean HRQoL was found to be $46.17 \%$ (SD 27.95). The lowest score was for role limitation due to physical health at $29.55 \%$ (SD 43.39), while the highest was for emotional well-being at $58.27 \%$ (SD 22.81). The overall mean scores were significantly lower among adult patients compared to their healthy counterparts, which was due to significantly lower scores in all domains (All with $\mathrm{P}<0.001$ ) [Table 3B]. While there were no significant difference between males and females in adult patients' group overall and within each domain. Furthermore, the overall HRQoL mean in adults was significantly lower than that of children $(\mathrm{p}=0.02)$.

Table (3A): HRQoL and Age Comparison between Patients with Sickle Cell Disease and their Healthy
Counterparts (Age 5-17 Years).
\begin{tabular}{lccccc} 
HRQoL Scores ( Mean \pm SD. ) \\
Category \\
\cline { 2 - 6 } & Physical & Emotional & Social & School & Mean \\
\hline Patients & $42.89 \pm 30.65$ & $63.66 \pm 24.4$ & $76.46 \pm 15.01$ & $69.63 \pm 20.7$ & $62.8 \pm 21.15$ \\
Controls & $78.44 \pm 13.95$ & $71.1 \pm 21.3$ & $88.78 \pm 12.08$ & $79.75 \pm 15.76$ & $79.11 \pm 12.44$ \\
P-value & $<0.001$ & 0.145 & $<0.001$ & 0.027 & $<0.001$ \\
\hline
\end{tabular}

\begin{tabular}{|c|c|c|c|c|c|c|c|c|c|}
\hline \multirow[b]{2}{*}{ Category } & \multicolumn{9}{|c|}{ HRQoL Scores (Mean \pm SD) } \\
\hline & $\begin{array}{l}\text { Physical } \\
\text { function } \\
\text { ing }\end{array}$ & $\begin{array}{c}\text { Role- } \\
\text { Physica } \\
\text { l }\end{array}$ & $\begin{array}{c}\text { Role- } \\
\text { Emotio } \\
\text { nal }\end{array}$ & $\begin{array}{l}\text { Energy- } \\
\text { Fatigue }\end{array}$ & $\begin{array}{l}\text { Social } \\
\text { functio } \\
\text { ning }\end{array}$ & Pain & $\begin{array}{l}\text { General } \\
\text { health }\end{array}$ & $\begin{array}{l}\text { Emotional } \\
\text { well-being }\end{array}$ & Mean \\
\hline Patients & $\begin{array}{l}52.5 \pm \\
30.22\end{array}$ & $\begin{array}{c}29.55 \pm 4 \\
3.39\end{array}$ & $\begin{array}{c}36.36 \pm 4 \\
9.23\end{array}$ & $\begin{array}{c}50.91 \pm 25 \\
43\end{array}$ & $\begin{array}{c}55.34 \pm 2 \\
9.4\end{array}$ & $\begin{array}{c}44.89 \pm 3 \\
3.98\end{array}$ & $41.73 \pm 21.14$ & $\begin{array}{c}58.27 \pm \\
22.81\end{array}$ & $\begin{array}{c}46.17 \pm \\
27.95\end{array}$ \\
\hline Controls & $\begin{array}{c}80.23 \pm 1 \\
4.01\end{array}$ & $\begin{array}{c}78.41 \pm 1 \\
9.35\end{array}$ & $\begin{array}{c}82.57 \pm 1 \\
6.65\end{array}$ & $\begin{array}{c}77.27 \pm 11 \\
31\end{array}$ & $\begin{array}{c}90.34 \pm 1 \\
8.87\end{array}$ & $\begin{array}{c}86.14 \pm 1 \\
4.26\end{array}$ & $79.55 \pm 9.24$ & $\begin{array}{c}82.73 \pm \\
10.64\end{array}$ & $\begin{array}{c}82.15 \pm \\
8.87\end{array}$ \\
\hline P-value & $<0.001$ & $<0.001$ & $<0.001$ & $<0.001$ & $<0.001$ & $<0.001$ & $<0.001$ & $<0.001$ & $<0.001$ \\
\hline
\end{tabular}

Table 4 shows HRQoL overall mean and its relevance to some clinical and laboratory parameters for all 63 patients. It was documented that those with at least one painful episodes, S. Ferritin $\geq 2500$ $\mathrm{ng} / \mathrm{ml}, \mathrm{S}$. LDH $\geq 700 \mathrm{U} / \mathrm{ml}$ and 3 or more blood transfusion/year, had significantly lower mean HRQoL scores when compared to those with no such events.
Though $\mathrm{Hb}<9 \mathrm{~g} / \mathrm{dl}$, reticulocyte count $>10 \%$, and $\mathrm{Hb} \mathrm{F}<10 \%$ were associated with lower mean HRQoL scores, however none were statistically significant. Moreover, table 4 also shows that those with low socioeconomic status had lower mean HRQoL when compared to those with middle/high status, though this was not statistically significant. 
Table (4) Mean of HRQoL and its Relevance to some Clinical and Laboratory Parameters.

\section{Parameters}

HRQoL of overall patients ( Mean \pm SD. )

Painful episodes requiring admission /12 months

\section{No}

Yes

P-value

Transfusion frequency /12 months

$$
<3
$$$$
\geq 3
$$

S.Ferritin

Hemoglobin.$$
\text { P-value }
$$

$$
<2500 \mathrm{ng} / \mathrm{ml}
$$$$
\geq 2500 \mathrm{ng} / \mathrm{ml}
$$

P-value

$$
\geq 9 \mathrm{gm} / \mathrm{dl}
$$$$
<9 \mathrm{gm} / \mathrm{dl}
$$

Leucocyte count.

P-value

$$
\begin{aligned}
& <11,000 / \mathrm{mm}^{3} \\
& \geq 11,000 / \mathrm{mm}^{3}
\end{aligned}
$$

Retic. Count

$$
\text { P-value }
$$

$$
<10 \%
$$$$
\geq 10 \%
$$

P-value

L.D.H.

$\mathrm{Hb} \mathrm{F} \%$

$$
\begin{array}{ll} 
& <700 \mathrm{U} / \mathrm{L} \\
& \geq 700 \mathrm{U} / \mathrm{L}
\end{array}
$$

$$
\begin{aligned}
& <10 \% \\
& \geq 10 \%
\end{aligned}
$$

P-value

Avascular necrosis femoral head

$$
\begin{array}{cr} 
& \text { No } \\
\text { P-value } & \text { Yes }
\end{array}
$$

Socioeconomic status

$$
\text { P-value }
$$

$63.18 \pm 23.47$

$48.74 \pm 24.62$

0.02

$61.56 \pm 26.78$

$46.42 \pm 15.58$

0.007

$61.18 \pm 25.24$

$44.36 \pm 18.91$

0.012

$59.13 \pm 28.62$

$55.68 \pm 22.5$

$55.47 \pm 25.6$

$59.16 \pm 24.03$

0.5

$59.94 \pm 26.9$

$55.62 \pm 24.03$

$60.19 \pm 26.76$

$47.21 \pm 11.65$

0.025

$54.04 \pm 25.96$

$60.78 \pm 24.53$

0.327

$59.83 \pm 23.62$

$24.18 \pm 12.43$

0.002

$53.04 \pm 25.17$

$61.63 \pm 24.06$

0.173

\section{DISCUSSION}

On the other hand, except for avascular necrosis (AVN) of femoral head seen in $5 / 63$ patients, all other cumulative events/crises were sporadic or absent among enrollees. AVN was found to be significantly associated with much lower quality of life $(\mathrm{p}=0.002)$
The measurement of the health-related quality of life in sickle cell disease has emerged as a valuable tool to assess the patient's perspective of their disease, and aid the attending physicians when considering various available management options as well as in predicting possible outcomes $^{5,10}$. Multiple tools for assessing 
HRQoL have been introduced over the years, however PedsQL 4.0 generic tool for children and SF-36 for adults have gained popularity because of their reliability, validity and reproducibility $y^{3,5,11-}$ 14.

The main finding of this study was that patients with SCD from Akre, had significantly lower health related quality of life compared to their healthy counterparts, whether children or adults. This is consistent with the bulk of the literature on children $^{5,9,10,12,15-17}$, and on adults ${ }^{18-22}$.

The most important contributor to the lower overall mean HRQoL in children was reduction in physical functioning domain, which is similar to that reported in other SCD populations like Southern Iraqis, American blacks, Tanzanians, and Brazilians $^{9,23-25}$. While the main contributor to lower overall mean HRQoL in adults was reduction in role physical, which is also consistent with studies on Saudi Arabian and African American patients, which showed that this domain is either the worst or among the worst affected $^{18-20,26}$.

An important observation of the current study is that the overall mean HRQoL was much lower in adults than children, which is going with notion that with advancing age there is increasing organ damage and morbidity, thus a worse quality of life. This is consistent with observations from African Americans and Saudi Arabian SCD patients ${ }^{15,18,20}$.

Among the predictors identified in association with worse HRQoL in the current study is the occurrence of pain crises, which was also well documented by many studies worldwide in both children and adults $9,17,21,26-30$. Another identified predictor of worse $\mathrm{HRQoL}$ is transfusion frequency, again noted by several earlier studies worldwide ${ }^{19,31}$. The latter, as well as higher S. Ferritin, LDH and reticulocytes, lower $\mathrm{Hb}$ and $\mathrm{HbF} \%$, are actually associated with more severe disease and thus higher rates of hemolysis and more transfusions, and eventually more organ damage and worse quality of life. Though it should be noted that though all these five parameters were associated with lower mean HRQoL, however this was significant in the first two only. This could probably be explained by the limitation of the number of registered SCD patients that were available at the center.

The scarcity of the cumulative events related to SCD in the current cohort, may be related to the moderate severity of the SCD in this locality ${ }^{32}$, but may be also due to the fact that some events were not documented in the patients' records and despite the best efforts of the researchers may have been missed due to illiteracy of most the patients and their parents. However, it has been noted by earlier studies, that it is the pain episodes and socioeconomic status that is likely to be related to HRQoL and not the cumulative events relevant to the disease ${ }^{30}$, with the exception of AVN as documented by at least one study and as shown in our own observations ${ }^{18}$.

In conclusion, it appears that HRQoL in both children and adults with SCD in Akre thalassemia center is worse than their healthy counterparts. Furthermore, it appears that the main predictors of HRQoL are the occurrence of pain episodes, more frequent transfusions and higher serum Ferritin and LDH. Studies including SCD 


\section{HEALTH-RELATED OUALITY OF LIFE IN SICKLE CELL DISEASE}

patients in other centers in the Kurdistan region are warranted.

\section{REFERENCES}

1. Stuart MJ, Nagel RL. Sickle-cell disease. Lancet. 2004; 364:1343-1360.

2. Sehlo MG, Kamfar HZ. Depression and quality of life in children with sickle cell disease: effect of social support. BMC Psychiatry. 2015; 15: 78.

3. Hays RD, Morales LS. The RAND-36 measure of health related quality of life. Ann Med. 2001; 33:350-357.

4. Varni JW, Seid M, Kurtin PS. PedsQL ${ }^{\text {TM }}$ 4.0: Reliability and validity of the Pediatric Quality of Life Inventory ${ }^{\mathrm{TM}}$ Version 4.0 Generic Core Scales in healthy and patient populations. Med Care. 2001; 39(8):800-812.

5. Panepinto JA. Health-related quality of life in patients with hemoglobinopathies. ASH Education Program Book. 2012; 2012(1): 284289.

6. https:// www.rand.org/healthcare/surveys_tools/mos-F36-itemshort-form accessed on 23rd December 2018.

7. Ware JE Jr, Sherbourne CD. The MOS 36-item short-form health survey (SF-36). I. conceptual framework and item selection. Med Care. 1992; 30:473-483.

8. Mikael NA, Al-Allawi NAS. Factors affecting the quality of life in children and adolescents with thalassemia in Iraqi Kurdistan. Saudi Med J. 2018; 39 (8): 799-807

9. Menezes AS, Len CA, Hilário MO, Terreri MT, Braga JA. Quality of life in patients with sickle cell disease. Rev Paul Pediatr. 2013; 31(1): 24-29.

10. Panepinto JA, O'mahar KM, DeBaun MR, Loberiza FR, Scott JP. Healthrelated quality of life in children with sickle cell disease: child and parent perception. Brit J Haematol. 2005; 130(3): 437-444.

11. Varni JW, Burwinkle TM, Seid M, Skarr D. The PedsQLTM* 4.0 as a pediatric population health measure: Feasibility, reliability, and validity. Ambul Pediatr. 2003; 3(6): 329-341.

12. Dale JC, Cochran CJ, Roy L, Jernigan E, Buchanan GR. Health-related quality of life in children and adolescents with sickle cell disease. J Pediatr Health Care. 2011; 25(4): 208215.

13. Rijken M, van Kerkhof M, Dekker J, Schellevis FG. Comorbidity of chronic diseases: effect of disease pairs on physical and mental functioning. Qual Life Res. 2005; 14:45-55.

14. Alonso J, Ferrer M, Gandek B, Ware JE Jr, Aaronson K, Mosconi P, et al. Health-related quality of life associated with chronic conditions in eight countries: results from the international quality of life assessment (IQOLA) project. Qual Life Res. 2004; 13: 283-298.

15. Amr MA, Amin TT, Al-Omair OA. Health related quality of life among adolescents with sickle cell disease in Saudi Arabia. Pan African Medical Journal. 2011; 8:10.

16. Matos MA, Malheiros $C D$, Matos SSR. Health Related Quality of Life of Patients .with Sickle Cell Disease. J 
Blood Disord Transfus. 2016; 7(2): 345-348.

17. Ojelabi AO, Graham Y, Ling J. Health-related Quality of Life Predictors in Children and Adolescents with Sickle Cell Disease: A Systematic Review. Int. J Trop Dis Hlth. 2017; 22(2): 1-14.

18. Dampier $C$, LeBeau $P$, Rhee $S$, Lieff S, Kesler K, Ballas S, et al. Healthrelated quality of life in adults with sickle cell disease (SCD): a report from the comprehensive sickle cell centers clinical trial consortium. Am J Hematol. 2011;86(2):203-5.

19. Ahmed AE, Alaskar AS, Al-Suliman AM, Jazieh AR, McClish DK, Al Salamah M, et al. Health-related quality of life in patients with sickle cell disease in Saudi Arabia. Health Qual Life Outcomes. 2015;13:183.

20. Ahmed AE, Alaskar AS, McClish DK, Ali YZ, Malhan HM, Aldughither $M H$, et al. SCD in Saudi children, teens, and adults: A study in healthrelated quality of life. J blood Disord. 2016; 3 (1):1036.

21. Freitas SLF, Ivo ML, Figueiredo MS, Gerk MAS, Nunes CB, Monteiro FF. Quality of life in adults with sickle cell disease: an integrative review of the literature. Revista Brasileira de Enfermagem. 2018; 71(1), 195-205

22. Nwogoh B, Ofovwe CE, Omati CE. Health-related quality of life in Sickle cell disease subjects in Benin city, Nigeria. Afr. J. Med Health Sci. 2016; 15: 80-85.

23. Hassan MK. Health Related Quality of Life (HRQoL) of Patients with Thalassemia and Sickle Cell Disease and the Impact of these Diseases on
Families. Proceedings of the Academy for sickle cell and thalassaemia conference (ASCAT), 2016 Oct 5-7; London.

24. Panepinto JA, Beverung LM., Varni JW. Clinically meaningful interpretation of pediatric healthrelated quality of life in sickle cell disease. J Pediatr Hematol/Oncol. 2015; 37(2): 128-133.

25. Bhatia M, Kolva E, Cimini L, Jin Z, Satwani P, Savone M, et al. Health-related quality of life after allogeneic hematopoietic stem cell transplantation for sickle cell disease. Biol Blood Marrow Transplant. 2015; 21(4): 666-672.

26. McClish DK, Penberthy LT, Bovbjerg VE, Roberts JD; Aisiku IP, Levenson JL, et al. Health related quality of life in sickle cell patients: The PiSCES project. Health Qual Life Outcomes. 2005; 3(50):1-7.

27. Schlenz AM, Schatz J, McClellan CB, Roberts CW. Responsiveness of the PedsQL to pain-related changes in health-related quality of life in pediatric sickle cell disease. J Pediatr Psychol. 2012; 37(7): 798-807.

28. Anie KA, Steptoe A, Bevan D. Sickle cell disease: Pain, coping and quality of life in a study of adults in the UK. Br J of Health Psychol. 2002; 7(3): 331-344.

29. Martínez-Triana R, MartínezRodríguez M, Guerra-Romero C, Guerra-González EM, MachadoAlmeida T, Machín-García S, et al. Cuestionario para evaluar la calidad de vida relacionada con la salud de adultos con drepanocitosis. Rev Cuba 
Hematol Inmunol Hemoter. 2012; 28:385-97. [abst]

30. van Tuijn $C F$, van Beers EJ, Schnog JJ, Biemond BJ. Pain rate and social circumstances rather than cumulative organ damage determine the quality of life in adults with sickle cell disease. Am J Hematol. 2010;85(7):532-5.

31. Pereira SAS, Brener S, Cardoso CS, Proietti ABFC. Sickle Cell Disease: quality of life in patients with hemoglobin SS and SC disorders. Rev Bras Hematol Hemoter. 2013; 35(5): 325-31.
32. Al-Allawi N, Qadir SMA, Puehringer H, Chui DHK, Farrell JJ, Oberkanins C. The association of HBG2, BCL11A, and HMIP polymorphisms with fetal hemoglobin and clinical phenotype in Iraqi Kurds with sickle cell disease. Int. J Lab Hematol. 2019 ;41(1):87-93 


\section{ثوختة}

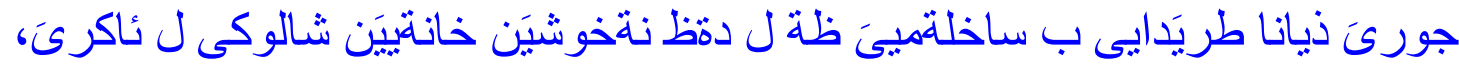

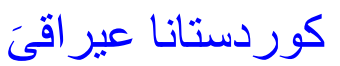

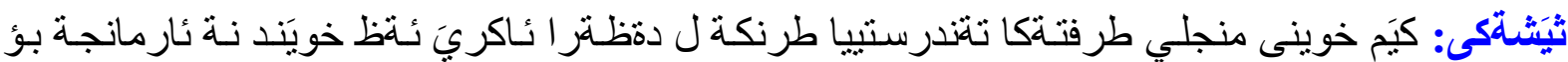

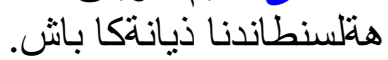

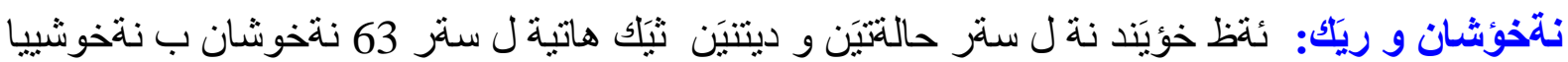

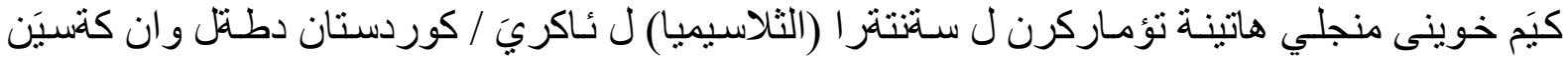

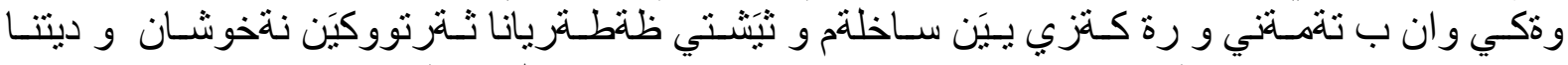

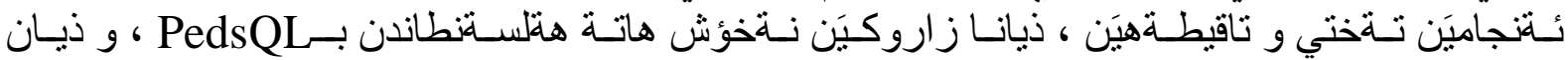

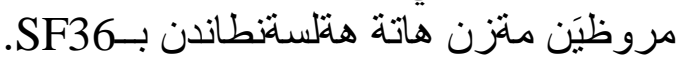

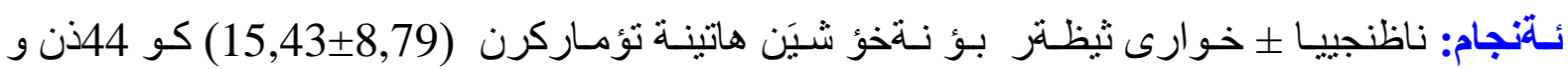

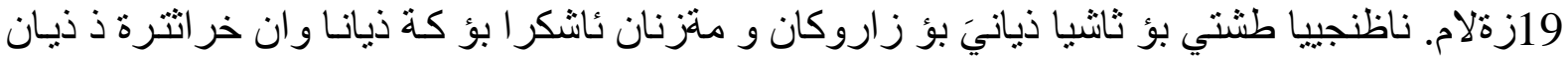

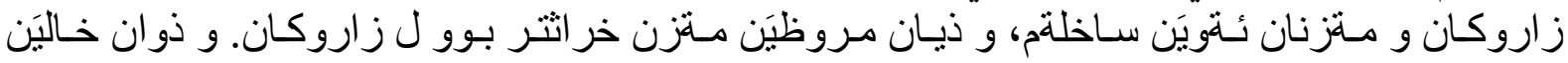

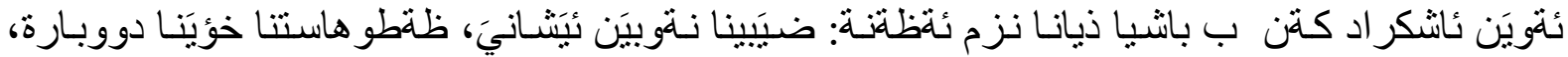

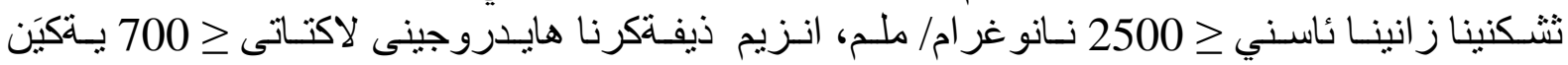

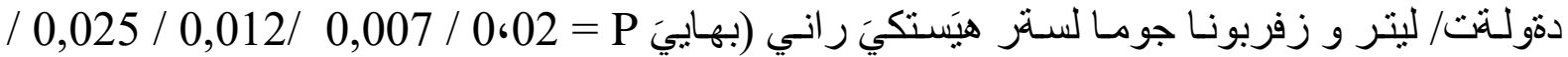
(0,002 لسنة يةكي).

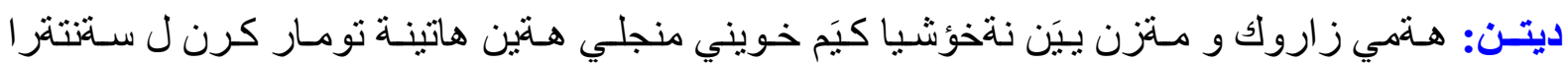

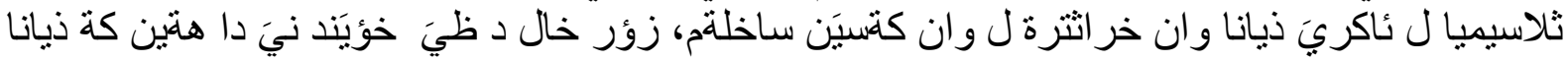

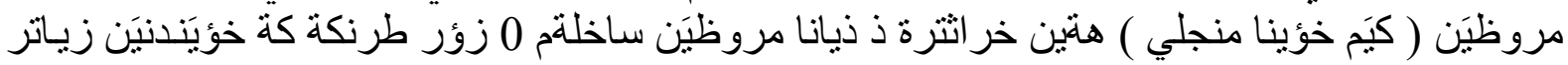

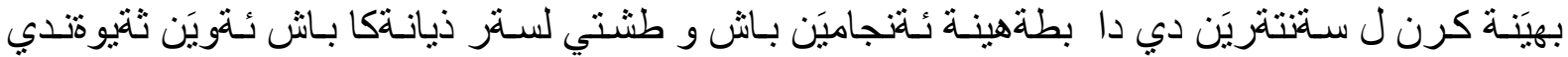

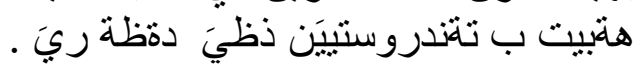


نوعية الحياة المتعلقة بالصحة في مرضى الخلايا المنجلية في عقره ، كردستان العرق

الهاف: فقر الدم المنجلي هي مشكلة صحية مهمة في منطقة عقرة , وهذه الدراسة تهدف الى تقييم جودة الحياة في هذه الحالة. المرضى والطرق: تم دراسة مجموع 63 مريض بفقر الدم المنجلي تم تسجيلهم في مركز الثلاسيميا بعقرة/

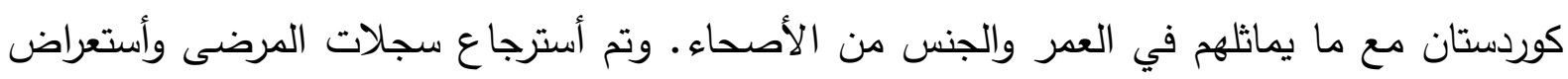

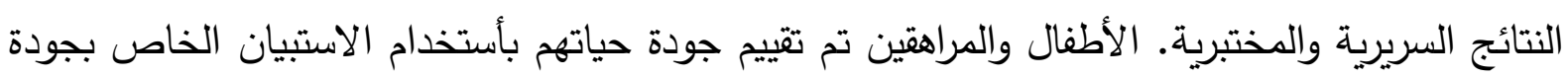

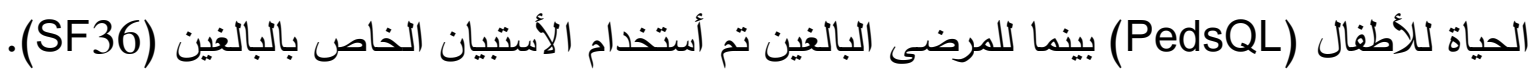

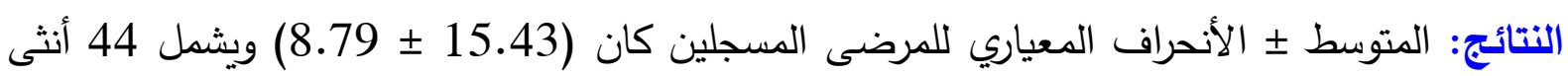

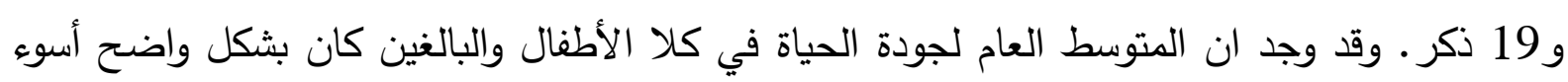

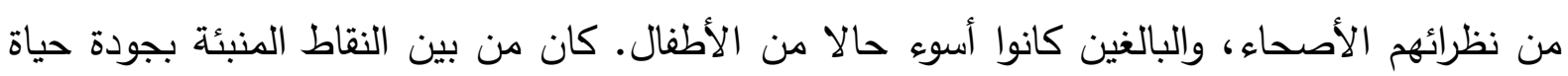

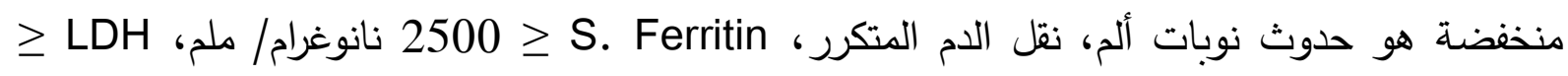

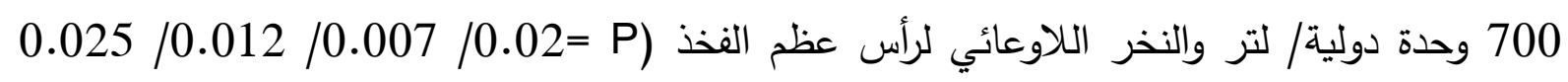

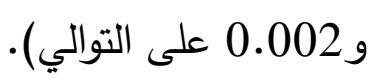
الاستنتاجات: وجد أن كلا من الأطفال والبالغين المصابين بمرض فقر الدم المنجلي المسجلين في مركز

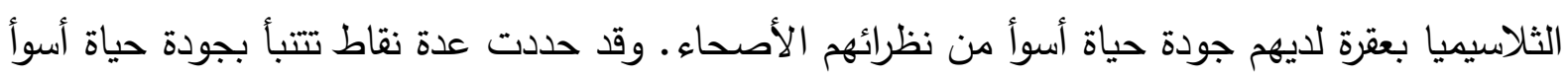

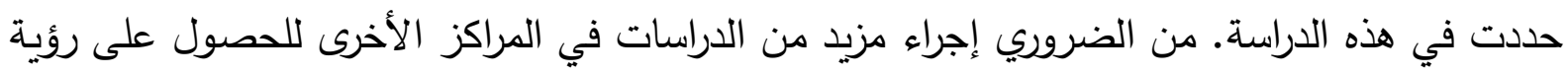

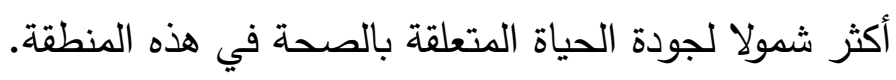

